\title{
INVESTIGATING THE FLOW CHARACTRISTICS DUE TO CHUTE AND BAFFLE BLOCKS (Case Study: New Assiut Barrage Spillway)
}

\author{
Mahgoub S.E, Ali A ... M and Seif H. M. \\ Associate Professor, Hydraulics Research Institute, National Water Research Center, Egypt \\ Researcher, Hydraulics Research Institute, National Water Research Center, Egypt \\ Professor, Channel Maintenance Research Institute, National Water Research Center, Egypt
}

\begin{abstract}
The present study investigates the flow characteristics at the vicinity of the New Assiut Barrage, NAB, sluiceway with baffles using a 2-D flume model. Head losses between the upstream and downstream of the sluiceway gate, pressure along the inclined drop and on the horizontal apron were measure and calculated. Local head losses due to sill and flow velocities were measured. Ten tests for fully opened gate (flood evacuation) were carried out. Two tests were conducted to test the cases before and after implementing of chute-blocks on the inclined drop together with baffled apron. During these tests, the velocity was varied between $4.0 \mathrm{~m} / \mathrm{s}$ to 4.5 $\mathrm{m} / \mathrm{s}$ by varying the discharges from $5000 \mathrm{~m} 3 / \mathrm{s}$ to $7000 \mathrm{~m} 3 / \mathrm{s}$. The results showed that, the maximum calculated head loss after installing the chute and baffle blocks were $0.02 \mathrm{~m}$ and $0.27 \mathrm{~m}$ when the flow discharge was increased from 5000 to $7000 \mathrm{~m} 3 / \mathrm{s}$, respectively (i.e. the losses increased by $92.6 \%$ when the discharge increased by $28.5 \%$ ). The maximum measured head losses after installing the chute and baffle blocks were $0.03 \mathrm{~m}$ and $0.23 \mathrm{~m}$ when the discharge was increased from $5000 \mathrm{~m} 3 / \mathrm{s}$ to $7000 \mathrm{~m} 3 / \mathrm{s}$, respectively (i.e. the losses increased by $87 \%$ when the discharge increased by $28.5 \%$ ). On the other hand, the maximum pressure values before and after installing the chute and baffle blocks were $13.9 \mathrm{~m}$ and $13.93 \mathrm{~m}$ at a discharge of $5000 \mathrm{~m} 3 / \mathrm{s}$. These values were $15.44 \mathrm{~m}$ and $16.14 \mathrm{~m}$ at a discharge of $7000 \mathrm{~m} 3 / \mathrm{s}$. The study concluded that adding the chute and baffle blocks has no sensible effect on the pressure and the head losses values.
\end{abstract}

Keywords: Sluiceway; Chute; Baffle Blocks; Head Losses; Velocity and Pressure Distribution.

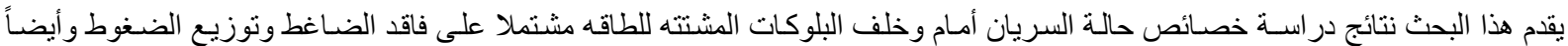

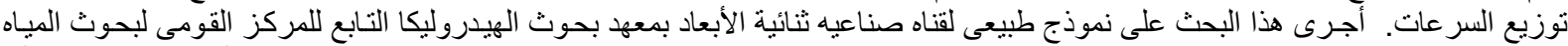

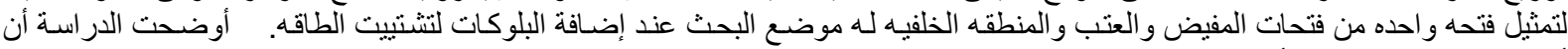

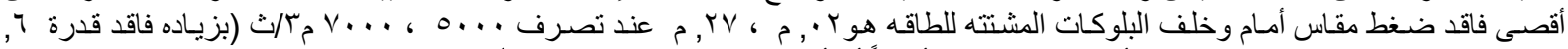

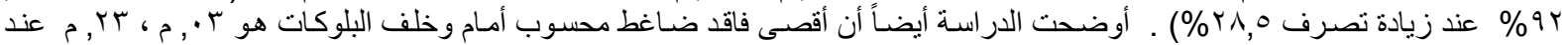

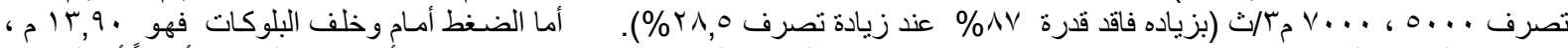

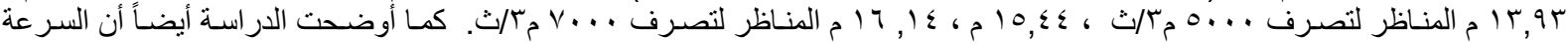

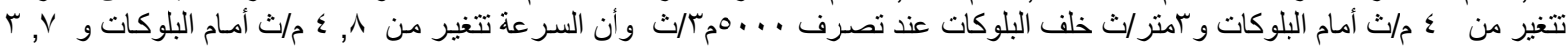

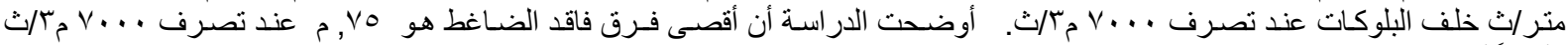

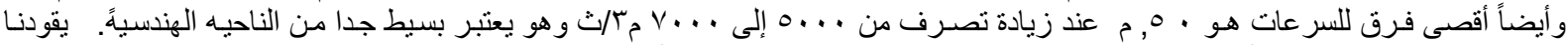

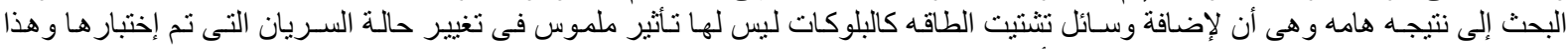

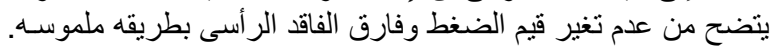




\section{INTRODUCTION}

The Existing Assiut Barrage (EAB) is located $530 \mathrm{~km}$ downstream of Aswan High Dam (AHD). The barrage was completed in 1902 . It has 110 vents of $5.0 \mathrm{~m}$ each. Since its completion in 1902, the $\mathrm{EAB}$ was functioning well with a maximum head of $4.2 \mathrm{~m}$. Seepage and uplift pressures under the barrage have increased due to degradation in the river bed at the downstream side since the closure of the AHD in 1968. The barrage was remodeled extensively between 1934 and 1938 in order to increase the Ibrahimia Canal capacity of $350 \mathrm{~km}$ long irrigating an area of 1.645 million feddan.

Moreover, the barrage is facing severe problems due to the ageing of the construction material. For these reasons, the Ministry of Water Resources and Irrigation (MWRI), decided to replace the existing barrage by a new one which necessitates a hydraulic model study to test the feasibility of constructing NAB.

The main objectives of this study are to investigate the flow characteristics due to the chute and baffle blocks, using one bay of the sluiceway radial gate for "fully opened gate" case, to measure the water levels differences between head-pond and tail-water point gauges, to calculate the hydraulic head losses, and to measure the pressure and velocity distribution on the horizontal apron.

\section{MODEL DESCRIPTION}

A 2-D flume model was used to one sluiceway bay to simulate the flow pattern upstream and downstream of the structure. This was achieved in order to undergo further 3-D hydraulic scale model testing to the barrage layout. The 3-D model is devoted to test the discharge capacity and hydraulic performance of the sluiceway with the objective of confirming and optimizing the levels of the sluiceway sill and apron together with its length.

A 2-D flume model with an undistorted scale of 1:21 was designed to represent $500 \mathrm{~m}$ of the Nile River together with one bay of the sluiceway, the sill with its downstream apron, and the rip-rap protection. The model structure, Figure (1), is made of Plexiglas material in a $26 \mathrm{~m}$ long, $1 \mathrm{~m}$ wide and $1.2 \mathrm{~m}$ deep steel-framed glass walled flume. The glass panels allow visual inspection and photographing of the action of flow patterns and other related phenomena at the vicinity of the structure. The modeled structure consists of one bay of the sluice way that consists of two half piers of $4.0 \mathrm{~m}$ prototype width made of Plexiglas. A two parts radial gate made of brass (the lower part is the main radial gate and the upper part is the flap gate). Under normal operations, the flow passes between the radial gate and the wooden sill. The radial gate is operated by a gear box. The apron downstream of the sill, consists of 2 parts downward sloping part $(1: 1.74)$ followed by a horizontal apron. Both are made of water tight wood. The dimensions of the model are shown on Figure (2). Plate (1) and Figure (2) show the arrangement of the chute blocks on the inclined drop and the baffle blocks on the horizontal apron.

The flume is provided with a circulating feeding system. The maximum capacity of the feeding system is $560 \mathrm{l} / \mathrm{s}$. This capacity is sufficient as the maximum scaled discharge of the model is $495 \mathrm{l} / \mathrm{s}$. The required discharge is pumped directly by one pump from an isolated underground reservoir.

The model entrance consists of a $1.5 \mathrm{~m}$ wide, $2.0 \mathrm{~m}$ long and $2.0 \mathrm{~m}$ high steel basin. This basin is used to receive the delivered water from the two main pipelines of the circulating feeding system. A mesh box filled with coarse gravel followed by a wire mesh box filled with 2.0 inches diameter plastic pipes, are provided in order to dissipate the flow energy as well as to avoid any disturbance. Also, a bed ramp was shaped at the entrance to help in absorbing the rest of the flow energy before approaching the barrage model. The flow through the sluiceway bay was adjusted by means of the brass radial gate.

The model bed is formed of $2.5 \mathrm{~mm}$ mean diameter sand covered by coarser material (rip-rap) to protect upstream and downstream areas of the structure. The rip-rap protection is of mean diameter $16.2 \mathrm{~mm}, 23.8$ $\mathrm{mm}$, and $29.5 \mathrm{~mm}$ in the upstream reach, the upstream reach near the bay and the downstream reach, respectively. The thickness is $16.2 \mathrm{~mm}, 23.8 \mathrm{~mm}$, and $29.5 \mathrm{~mm}$ representing $340 \mathrm{~mm}, 500 \mathrm{~mm}$, and $620 \mathrm{~mm}$, respectively in the prototype. These layers were placed according to their level and location specified by the NAB consultants.

The model exit consists of a basin at the end of the simulated reach of the Nile River followed by a steel tail control gate in the downstream to adjust the water surface levels. 


\section{MODEL SIMILARITY}

In the model, the inertial and gravitational forces are dominant since the flow has free surface. In other words, the model was based on the Froude similarity in order to simulate the kinematics and dynamics of the flow field properly. The Froude number is given by:

$$
F_{r}=\frac{V}{\sqrt{g h}}
$$

Where:

$\mathrm{F}_{\mathrm{r}}$ : Froude number

$\mathrm{V}$ : Average flow velocity

h : Characteristic depth

$\mathrm{g}:$ Gravitational acceleration

$(\mathrm{m} / \mathrm{s})$

(m)

$\left(\mathrm{m} / \mathrm{s}^{2}\right)$

This implies that the velocity, discharge and time scale to be:

Velocity scale ratio

Discharge scale ratio

Time scale ratio $=\mathrm{n}_{\mathrm{t}}$

$$
\begin{array}{ll}
=\mathrm{n}_{\mathrm{v}} & =\left(\mathrm{n}_{\mathrm{h}}\right)^{0.5} \\
=\mathrm{n}_{\mathrm{D}} & =\mathrm{n}_{\mathrm{l}} \mathrm{n}_{\mathrm{h}} \mathrm{n}_{\mathrm{v}}=\mathrm{n}_{\mathrm{l}}\left(\mathrm{n}_{\mathrm{h}}\right)^{1.5} \\
=\mathrm{n}_{\mathrm{l}} / \mathrm{n}_{\mathrm{v}} & =\mathrm{n}_{\mathrm{l}} /\left(\mathrm{n}_{\mathrm{h}}\right)^{0.5}
\end{array}
$$

Consequently, the ratios for the other quantities are:

$\begin{array}{lll}\mathrm{n}_{\mathrm{h}} \text { : depth scale ratio } & \mathrm{h}_{\mathrm{p}} / \mathrm{h}_{\mathrm{m}}=21 \\ \mathrm{n}_{\mathrm{l}} \text { : length scale ratio } & \mathrm{l}_{\mathrm{p}} / \mathrm{l}_{\mathrm{m}} & =21 \\ \mathrm{n}_{\mathrm{a}} \text { : area scale ratio } & \mathrm{n}_{1}^{2} & =441 \\ \mathrm{n}_{\mathrm{v}}: \text { velocity scale ratio } & \mathrm{n}_{\mathrm{h}}{ }^{1 / 2} & =4.58, \\ \mathrm{n}_{\mathrm{D}} \text { : discharge scale ratio } & \mathrm{n}_{\mathrm{l}}^{2.5} & =2020.92 \\ \mathrm{n}_{\mathrm{t}} \text { : time scale ratio } & \mathrm{n}_{1}^{1 / 2} & =4.58\end{array}$

The model simulated different prototype discharges between $350 \mathrm{~m}^{3} / \mathrm{s}$ and $7000 \mathrm{~m}^{3} / \mathrm{s}$ taking into account the Froude similarity, the model discharge is given by :

$$
Q_{\text {model }}=\frac{1}{8} Q_{\text {Nile }} n_{h}^{-2.5}=0.00006185 \mathrm{Q}_{\text {Nile }}
$$

\section{Where:}

$$
\begin{array}{lll}
\mathrm{Q}_{\text {model }} & =\text { Flow Discharge in Model } & \left(\mathrm{m}^{3} / \mathrm{s}\right) \\
\mathrm{Q}_{\text {Nile }} & =\text { Flow Discharge in Prototype } & \left(\mathrm{m}^{3} / \mathrm{s}\right) \\
\mathrm{n}_{\mathrm{h}} & =\text { Depth scale ratio } \mathrm{h}_{\mathrm{p}} / \mathrm{h}_{\mathrm{m}} & (21)
\end{array}
$$

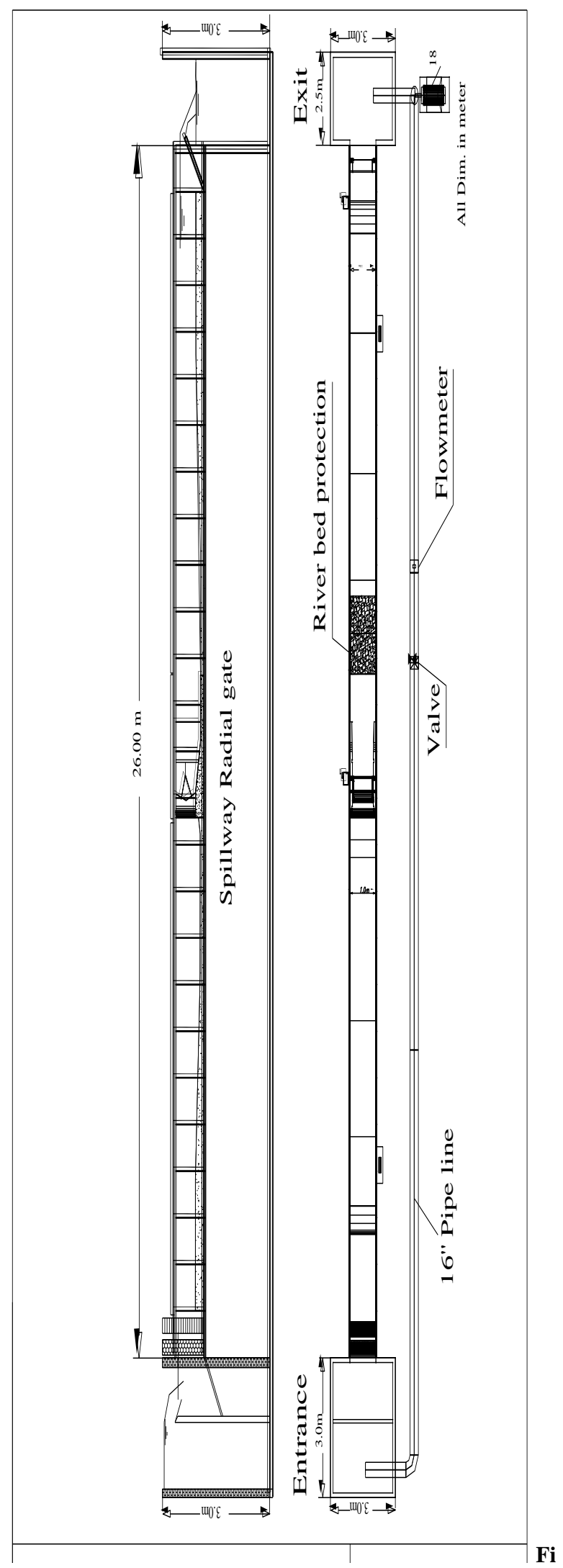

Figure 1: the Model Layout 


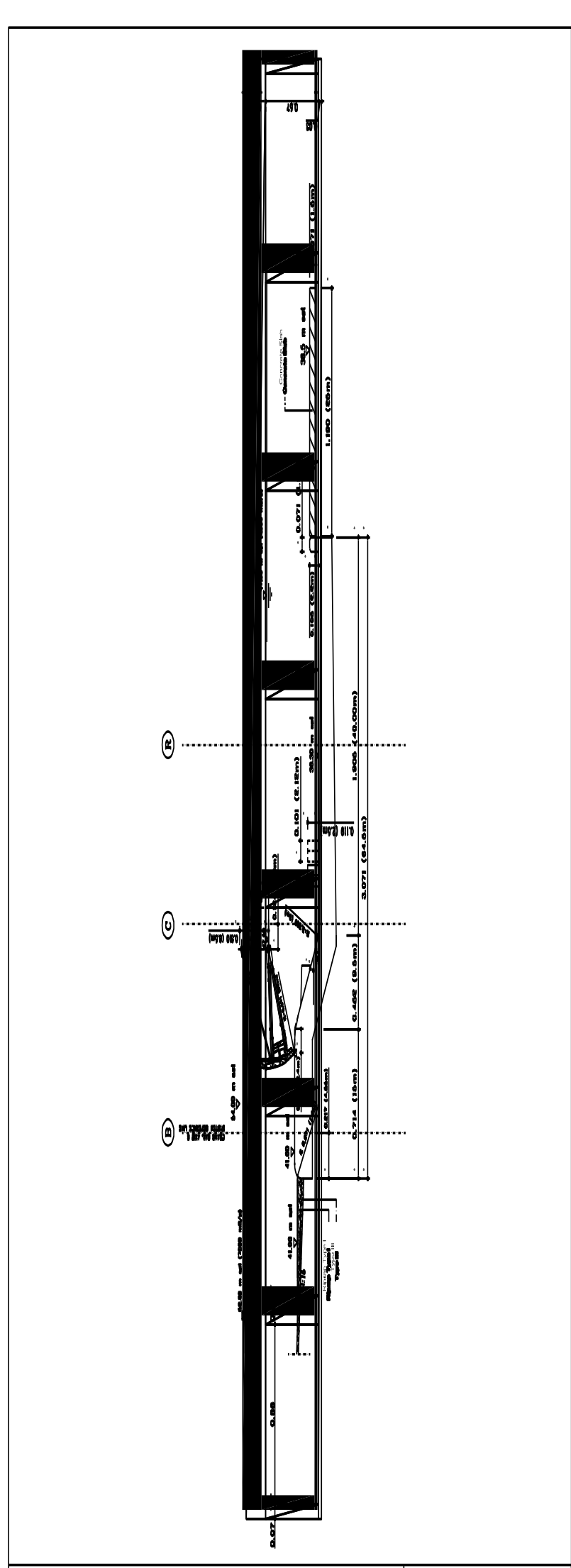

Figure 2 the Chute and Baffle Blocks in the Flume

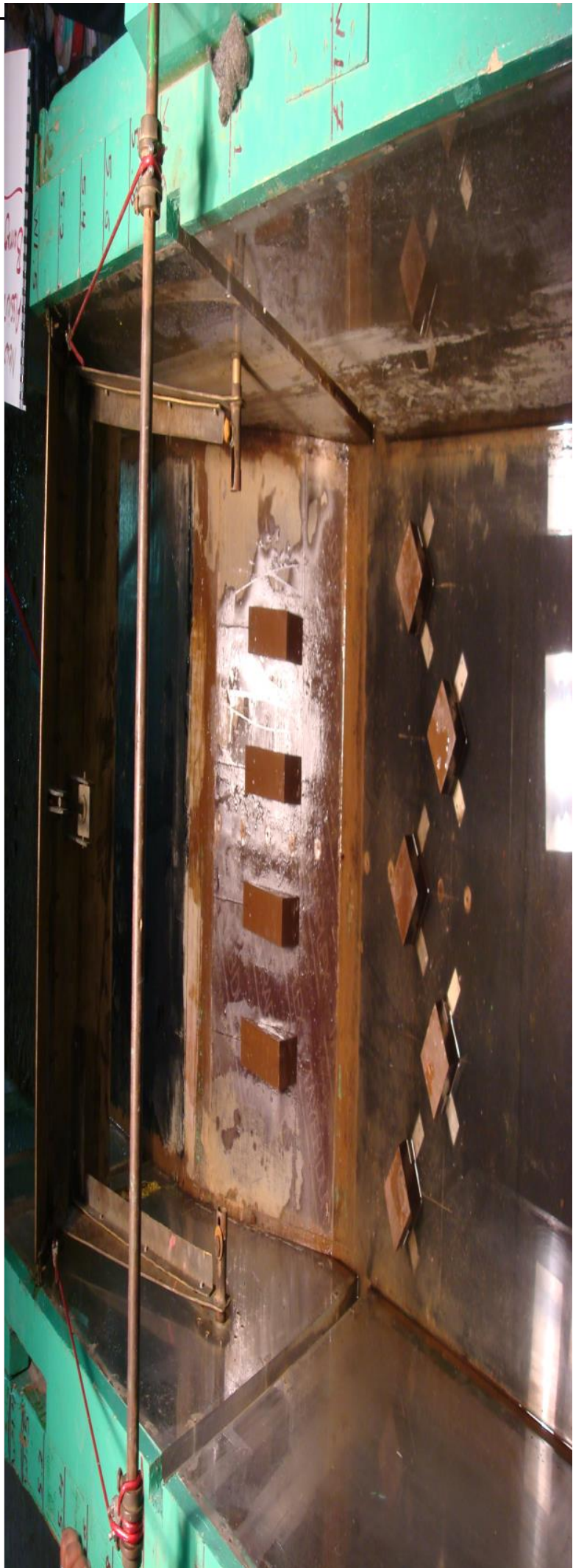

Plate (1) Installation of the Chute Blocks on the Inclined Drop and the Baffle Blocks

On the Horizontal Apron in the Flume Model 


\section{MEASURING INSTRUMENTS}

An Ultrasonic flow-meter with an accuracy of $\pm 1 \%$, was used to measure the discharge. It was installed on a 16 " diameter feeding pipe. The flow velocities were measured using an ElectroMagnetic current-meter type E.M.S. (manufactured by Delft Hydraulics). The device was connected to a mean value meter to show the average velocity within a selected time period.

To monitor the water levels, two point gauges with side stilling wells were installed 152 m downstream and $186 \mathrm{~m}$ upstream of the sluiceway crest (prototype scale). Also, a movable point gauge with an accuracy of $\pm 0.1 \mathrm{~mm}$ was used to measure the water level.

In order to measure the pressure on the horizontal apron, 12 cells $2 \mathrm{~m}$ apart (prototype scale) were fixed at the centerline of the apron surface. These cells were connected to 12 glass manometers fixed on a vertical board.

Video and photo cameras were also essential to record the flow patterns and to monitor the stability of the rip-rap.

\section{MODEL TEST PROGRAM}

Three stages of tests were carried out. Each stage contained series of tests to investigate the different flow characteristics. The group of tests that was simulating the flood evacuation was performed using range of flow discharges between $5000 \mathrm{~m}^{3} / \mathrm{s}$ and $7000 \mathrm{~m}^{3} / \mathrm{s}$. Two tests were carried out for the case of $5000 \mathrm{~m}^{3} / \mathrm{s}$ and $7000 \mathrm{~m}^{3} / \mathrm{s}$ corresponding to normal conditions and 50 years river bed degradation conditions as shown in Table (1) before and after adding the chute-blocks on the inclined drop together with the baffle-blocks on the horizontal apron.

\section{MEASUREMENTS}

During each test, the water level, flow velocity and pressure were measured. Water level

measurements were undertaken at the locations given by Table (2) and Figure (4), along the centre-line of the flume.

Velocity Measurements were performed at six cross sections, Figure (3) and table (1). Sections 1 to 6 are located at $0.1 ; 0.2 ; 0.4 ; 0.6 ; 0.8$ and 1.0 of $\mathrm{L}_{\text {tot }}$ $\left(\mathrm{L}_{\mathrm{tot}}=\mathrm{L}_{\mathrm{a}}+\mathrm{L}_{\mathrm{CS}}\right)$

$\mathrm{L}_{\text {tot }}$ total length of the concrete apron and extension slab

$\mathrm{L}_{\mathrm{a}} \quad$ length of the horizontal apron

$\mathrm{L}_{\mathrm{CS}}$ length of the concrete slab

For each cross section the velocity profile was measured at three verticals at the right, at the center, and at the left at 0.2, 0.4, 0.6, 0.8 and 0.9 of the water depth.

Pressure measurements were carried out at the drop of the gate sill at different locations to verify whether the pressure remains equal to the atmospheric pressure, e.g. the jet is not separated from the back slope of the sill twelve pressure cells were arranged at the drop, Figure (5) and (6). The pressure was also measured on the horizontal apron along the bay center line every $2 \mathrm{~m}$.

Table 1 Test for Fully Opened Spillway Gate

\begin{tabular}{||c|c|c|c||}
\hline $\begin{array}{c}\text { Test } \\
\text { No. }\end{array}$ & $\begin{array}{c}\text { Discharge } \\
\left(\mathrm{m}^{3} / \mathrm{s}\right)\end{array}$ & $\begin{array}{c}\text { U.S.W.L } \\
\mathrm{m}(+\mathrm{MSL})\end{array}$ & $\begin{array}{c}\text { D.S.W.L } \\
\mathrm{m}(+\mathrm{MSL})\end{array}$ \\
\hline \hline 1 & 5000 & Free & 50.00 \\
\hline 10 & 5000 & Free & 49.55 \\
\hline 2 & 5500 & Free & 50.35 \\
\hline 3 & 6000 & Free & 50.71 \\
\hline 4 & 7000 & Free & 51.45 \\
\hline 6 & 7000 & Free & 51.00 \\
\hline
\end{tabular}

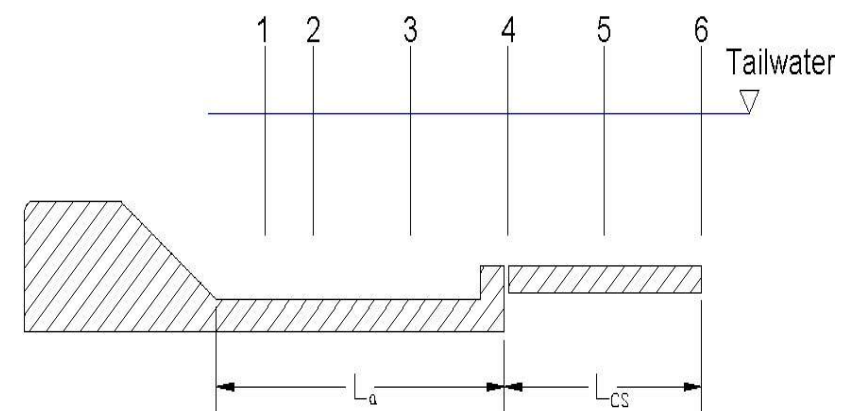

Figure 3 Locations of Velocity Measurements

Table 2 Locations of Water Level Measurements

\begin{tabular}{|c|l|}
\hline Location & Description \\
\hline \hline Head-pond & $\begin{array}{l}\text { Point gauge } 186 \mathrm{~m} \text { upstream of the } \\
\text { gate }\end{array}$ \\
\hline 1 & $60 \mathrm{~m}$ upstream of the sill \\
\hline 2 & $20 \mathrm{~m}$ upstream of the sill \\
\hline 3 & at the front of gate sill \\
\hline 4 & $\begin{array}{l}\text { directly behind the gate (when } \\
\text { opened) on the sill }\end{array}$ \\
\hline 5 & at the end of gate sill \\
\hline 6 & at the end of the drop \\
\hline 7 & end of drop $10.5 \mathrm{~m}$ \\
\hline 8 & end of drop $21 \mathrm{~m}$ \\
\hline 9 & end of drop $31.5 \mathrm{~m}$ \\
\hline 10 & end of drop $42 \mathrm{~m}$ \\
\hline 11 & end of drop $52.5 \mathrm{~m}$ \\
\hline 12 & end of drop $63.2 \mathrm{~m}$ \\
\hline Tail water & $\begin{array}{l}\text { Point gauge } 152 \mathrm{~m} \text { downstream of } \\
\text { the gate }\end{array}$ \\
\hline
\end{tabular}




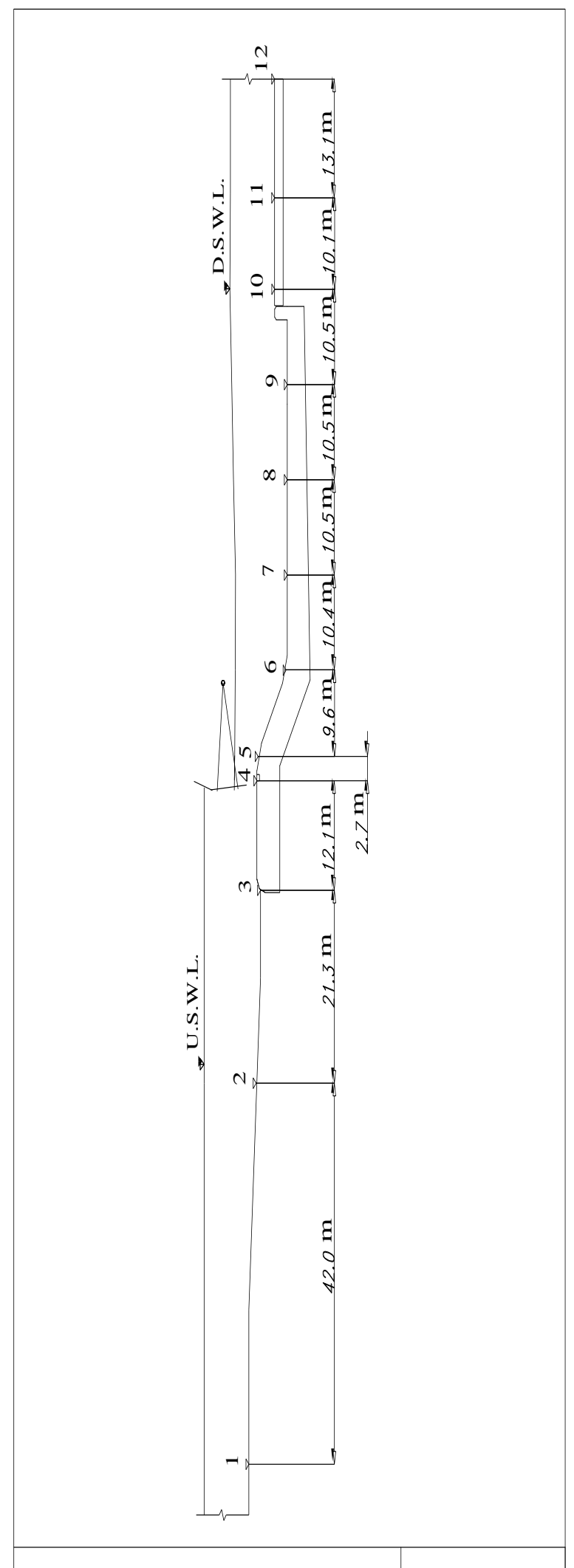

Figure 4 Water Level Measurements Locations

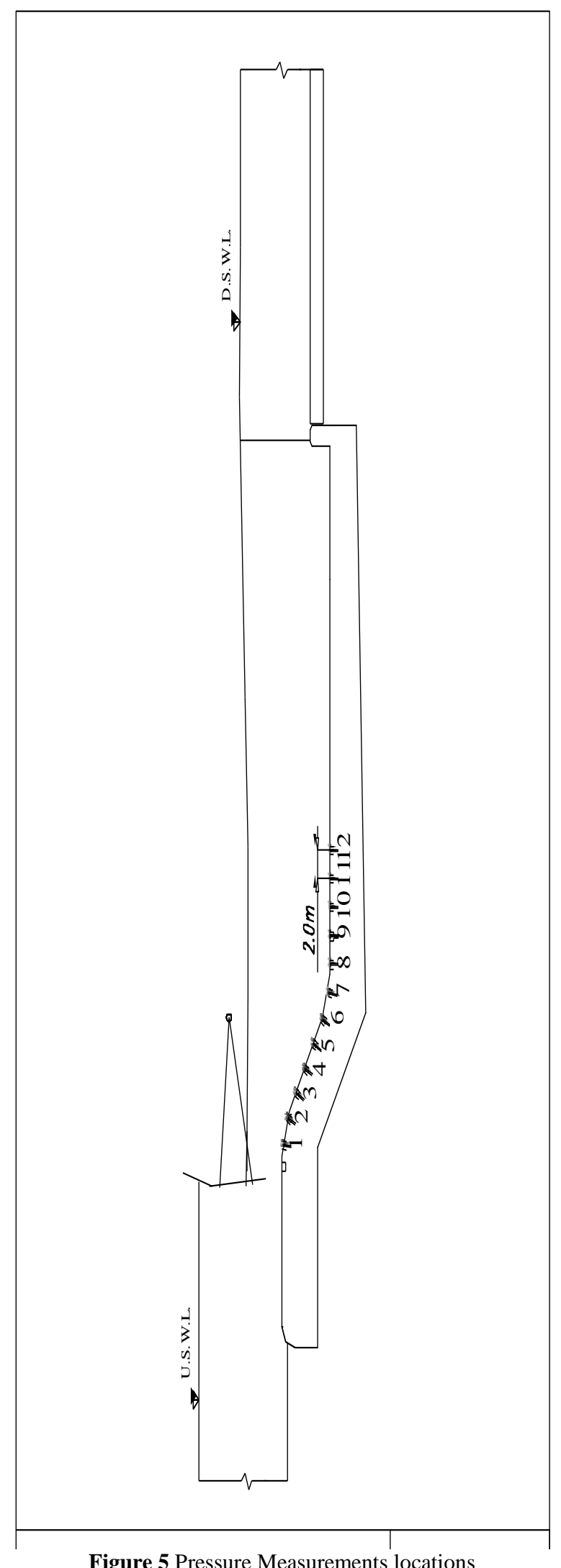

Figure 5 Pressure Measurements locations 


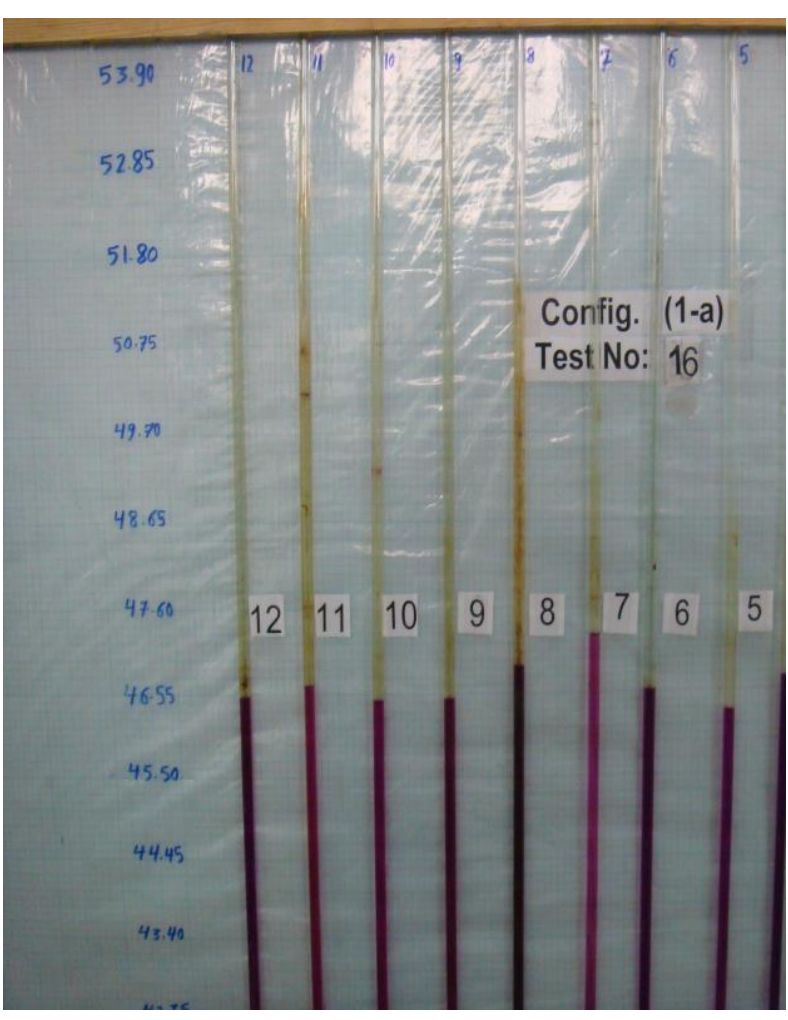

Figure 6 Piezometer Tubes Board for Measuring Pressure Distribution

\section{RESULTS ANALYSIS}

The head losses were calculated between the upstream and downstream of the sluice radial gate at cross-sections 1 and 2 (145.4 m upstream of the sluiceway radial gate and $204.6 \mathrm{~m}$ downstream of the gate for a wide range of discharges between $5000 \mathrm{~m}^{3} / \mathrm{s}$ and $7000 \mathrm{~m}^{3} / \mathrm{s}$ at the normal flow conditions. This was carried out after 50 years of river bed degradation and after installing the chute together with the baffle blocks.

The head losses were calculated using Bernoulli's equation as following:

$Z_{1}+H_{1}+\frac{V_{1}^{2}}{2 g}=Z_{2}+H_{2}+\frac{V_{2}^{2}}{2 g}+h_{L}$

where:

$\mathrm{Z}_{1} \quad$ : Upstream potential head

$\mathrm{Z}_{2} \quad$ : Downstream potential head

: Upstream water depth

$\mathrm{H}_{2} \quad$ : Downstream water depth

$V_{1} \quad$ : Upstream average velocity at cross section (1)

$V_{2} \quad$ : Downstream average velocity

At cross section (2)

$\mathrm{h}_{\mathrm{L}} \quad$ : Head losses between sec. 1 and 2 (m)
The measured water levels upstream and downstream of the gate sill elevation of (41.60) $\mathrm{m}+\mathrm{MSL}$ is presented in Table (4.1) for normal conditions, after 50 years of river bed degradation and after installing the chute and the baffle blocks. Also, the velocity values $\mathrm{v}_{1}$ and $\mathrm{v}_{2}$ were calculated using the discharge and the corresponding cross sectional area.

The maximum head loss values between cross sections 1 and 2 is $0.75 \mathrm{~m}$ for test No. 6 at discharge $7000 \mathrm{~m}^{3} / \mathrm{s}$ after 50 years of river bed degradation and after installing the chute and the baffle blocks is given in Tables (3).

For the pressure, it was measured at twelve locations on the inclined drop and on the horizontal apron using twelve pressure cells, $2 \mathrm{~m}$ apart as shown in Figure 6 . The results are shown in Table (4) and Figures (7.a) and (7.b) for the different discharges ranging from $5000 \mathrm{~m}^{3} / \mathrm{s}$ to $7000 \mathrm{~m}^{3} / \mathrm{s}$.

\section{CONCOLSUIONS}

From the results and analysis of this research, the following conclusions could be drawn out:

1. Comparing the head losses values before and after installing the chute and baffle blocks, it could be noticed that, the installation has a minimum effect on the losses.

2. Distribution of the pressure heads on the horizontal apron has the same trend. The maximum pressure head was found to be $15.44 \mathrm{~m}$ at pressure cell No. 12, corresponding to a discharge of $7000 \mathrm{~m}^{3} / \mathrm{s}$ at the normal condition. The maximum pressure head was found to be $16.14 \mathrm{~m}$ at pressure cell No. 12, corresponding to a discharge of $7000 \mathrm{~m}^{3} / \mathrm{s}$ after installing the chute and the baffle blocks.

3. The pressure values before and after installing the chute and baffle blocks have a slight effect on the pressure values.

4. As for the local head losses due to sill, the water level was measured at twelve (12) locations as shown in Figure (3) along the entire model length. The water level measurements are shown in Table (5) for the normal conditions, after 50 years of river bed degradation with the chute together with the baffle blocks.

5. The water level drop was investigated as shown in Table (6). It was noticed that, the maximum head losses due to sill was $0.48 \mathrm{~m}$ at test 10 discharge of $5000 \mathrm{~m}^{3} / \mathrm{s}$ after 50 years of river bed degradation. After installing the chute and the baffle blocks, the maximum head losses due to sill was $0.42 \mathrm{~m}$ at test one discharge $5000 \mathrm{~m}^{3} / \mathrm{s}$.

6. Comparing the head losses due to the sill before and after installing the chute and baffle blocks, it was clear that the installation induce a slight effect on the head losses values. 
7. Regarding the flow velocity, it was measured at six (6) cross sections as shown in Figure (5). For each cross section the velocity was measured at three (3) vertical points at the right, the center, and at the left at $0.2,0.4,0.6,0.8$ and 0.9 of the water depth .The measurements of the flow velocity were conducted in the downstream reach of the sluice way radial gate. Results of the velocity measurements are shown in Figures (8.a) and (8b) as a sample. The maximum velocity value was varied between $4.0 \mathrm{~m} / \mathrm{s}$ and $4.5 \mathrm{~m} / \mathrm{s}$ for tests No. 10 , 4 , and 6 at discharges $5000 \mathrm{~m}^{3} / \mathrm{s}$ and $7000 \mathrm{~m}^{3} / \mathrm{s}$.

\section{BIBLIOGRAPHY}

[1] Albertson, M., j.R. Bartan, and D.B. Simons, "Fluid Mechanics for Engineers", Prentice-Hall Civil Engineering Series, 1960.

[2] Bureau of Reclamation, "Hydraulic Laboratory Techniques", Second ed., rev. reprint, 1974.

[3] Bureau of Reclamation, "Hydraulic Laboratory Techniques" A Water Resources Technical Publication - U.S. Department of Interior, Denver - Colorado, 1980.

[4] CHOW V.T. Open Channel Hydraulics McGraw -Hill Auckland, Bogota Guatemala, Hamburg, Lisbon, London, etc., 1973.

[5] DREWES, U., Erosion Downstream of Stilling Basins Caused by High Turbulent RMISCH, K. Flows, $6^{\text {th }}$ Int. Symposium on River Sedimentation, 1995 New Delhi.

[6] De Vries, M. (1973), “Application of Physical and Mathematical Models for River Problems"; Delft Hydraulics Laboratory Publication No. 112.

[7] Faculty of Civil Engineering, Hydraulic and Geotech. Engineering Division, Delft University of Technology, Delft 1992.

[8] Hydraulic Model Investigations of the Sluiceway Hydraulic Research Institute, Delta Barrage 13621, Egypt. Report No. 42/1997.

[9] Hydraulic Model Investigations of the Sluiceway, Hydraulic Research Institute, Delta Barrage 13621, Egypt. Report No. by Eng. Abdel-Azim. M. Ali, January 1998.

[10]HOFFMANS, Two dimensional mathematical modeling of local scour holes G.J.C.M. Doctoral thesis, Communication No. 92-7

[11]Helmut Kobus, "Hydraulic Modeling",
German Association for Water Resources and Land Improvement, Bulletin 7.

[12] New Esna Barrage Physical Model Report, HRI, 1990. 
Table (3) Head Loss Calculations between Head-pond and Tail-water Sill Crest Elevation (41.60 m) + MSL/Apron Elevation (36.30 m) + MSL (After Installing the Chute and the Baffle Blocks)

\begin{tabular}{||l|l|l|l|l|l|l|l|l||}
\hline $\begin{array}{l}\text { Test } \\
\text { No. }\end{array}$ & $\mathrm{Q}$ & U.S. W.L & $\mathrm{V}_{1}$ & $\frac{V_{1}^{2}}{2 g}$ & D.S.W.L & $\mathrm{V}_{2}$ & $\frac{V_{2}^{2}}{2 g}$ & $\begin{array}{l}\mathrm{h}_{\mathrm{L}} \\
(\mathrm{m} / \mathrm{s})\end{array}$ \\
$(\mathrm{m})+\mathrm{mSL})$ & $(\mathrm{m} / \mathrm{s})$ & $\begin{array}{c}\mathrm{m}) \\
(\mathrm{m})+\mathrm{MSL}\end{array}$ & $(\mathrm{m})$ \\
\hline 1 & 5000 & 49.97 & 4.05 & 0.84 & 50.00 & 2.95 & 0.44 & 0.36 \\
\hline 10 & 5000 & 49.70 & 4.20 & 0.90 & 49.55 & 3.09 & 0.49 & 0.56 \\
\hline 2 & 5500 & 50.64 & 4.08 & 0.85 & 50.35 & 3.14 & 0.50 & 0.64 \\
\hline 3 & 6000 & 50.91 & 4.31 & 0.95 & 50.71 & 3.31 & 0.56 & 0.59 \\
\hline 4 & 7000 & 51.69 & 4.59 & 1.08 & 51.45 & 3.61 & 0.66 & 0.66 \\
\hline 6 & 7000 & 51.29 & 4.81 & 1.18 & 51.00 & 3.76 & 0.72 & 0.75 \\
\hline
\end{tabular}

\begin{tabular}{|c|c|c|c|c|c|c|c|c|}
\hline $\begin{array}{l}\text { Test } \\
\text { No. }\end{array}$ & $\begin{array}{l}Q \\
\left(\mathrm{~m}^{3} / \mathrm{s}\right)\end{array}$ & $\begin{array}{l}\text { U.S. W.L } \\
(\mathrm{m})+\mathrm{MSL}\end{array}$ & $\begin{array}{l}\mathrm{V}_{1} \\
(\mathrm{~m} / \mathrm{s})\end{array}$ & $\begin{array}{l}\frac{V_{1}^{2}}{2 g} \\
(\mathrm{~m})\end{array}$ & $\begin{array}{l}\text { D.S.W.L } \\
\text { (m)+ MSL }\end{array}$ & $\begin{array}{l}\mathrm{V}_{2} \\
(\mathrm{~m} / \mathrm{s})\end{array}$ & $\begin{array}{l}\frac{V_{2}^{2}}{2 g} \\
(\mathrm{~m})\end{array}$ & $\begin{array}{l}\mathrm{h}_{\mathrm{L}} \\
(\mathrm{m})\end{array}$ \\
\hline 1 & 5000 & 50.30 & 3.88 & 0.76 & 50.00 & 2.95 & 0.44 & 0.63 \\
\hline 10 & 5000 & 49.76 & 4.17 & 0.89 & 49.55 & 3.09 & 0.49 & 0.61 \\
\hline 2 & 5500 & 50.64 & 4.08 & 0.85 & 50.35 & 3.14 & 0.50 & 0.64 \\
\hline 3 & 6000 & 51.06 & 4.23 & 0.91 & 50.71 & 3.31 & 0.56 & 0.70 \\
\hline 4 & 7000 & 51.72 & 4.58 & 1.07 & 51.45 & 3.61 & 0.66 & 0.68 \\
\hline 6 & 7000 & 51.29 & 4.81 & 1.18 & 51.00 & 3.76 & 0.72 & 0.75 \\
\hline
\end{tabular}


Investigating the Flow Characteristics due to Chute and Baffle Blocks

Table 4: Pressure Distribution on the inclined drop and the Horizontal Apron for Fully Open Gate

Sill Crest Elevation (41.60 m) + MSL / Apron Elevation (36.30 m) + MSL

(Normal Conditions and after 50 years of Bed Degradation)

\begin{tabular}{|c|c|c|c|c|c|c|c|c|c|c|c|c|c|}
\hline \multirow{2}{*}{$\begin{array}{l}\text { Test } \\
\text { No. }\end{array}$} & \multirow{2}{*}{$\begin{array}{l}\mathrm{Q} \\
\mathrm{m}^{3} / \mathrm{s}\end{array}$} & \multicolumn{12}{|c|}{$\begin{array}{l}\text { Pressure head } \\
\text { (m) }\end{array}$} \\
\hline & & $\mathrm{P}_{1}$ & $\mathrm{P}_{2}$ & $\mathrm{P}_{3}$ & $\mathrm{P}_{4}$ & $\mathrm{P}_{5}$ & $\mathrm{P}_{6}$ & $\mathrm{P}_{7}$ & $\mathrm{P}_{8}$ & $\mathrm{P}_{9}$ & $\mathrm{P}_{10}$ & $\mathrm{P}_{11}$ & $\mathrm{P}_{12}$ \\
\hline 1 & 5000 & 8.06 & 9.37 & 10.09 & 11.07 & 12.07 & 13.09 & 13.72 & 13.72 & 13.76 & 13.84 & 13.88 & 13.90 \\
\hline 10 & 5000 & 7.49 & 8.87 & 9.61 & 10.59 & 11.57 & 12.63 & 13.23 & 13.25 & 13.30 & 13.34 & 13.42 & 13.46 \\
\hline 2 & 5500 & 8.31 & 9.71 & 10.43 & 11.41 & 12.45 & 13.49 & 14.09 & 14.11 & 14.14 & 14.20 & 14.28 & 14.28 \\
\hline 3 & 6000 & 8.60 & 10.05 & 10.77 & 11.75 & 12.79 & 13.79 & 14.41 & 14.47 & 14.51 & 14.53 & 14.58 & 14.68 \\
\hline 4 & 7000 & 9.21 & 10.72 & 11.44 & 12.48 & 13.50 & 14.50 & 15.12 & 15.19 & 15.21 & 15.25 & 15.35 & 15.44 \\
\hline 6 & 7000 & 8.90 & 10.28 & 11.00 & 12.02 & 13.04 & 14.06 & 14.74 & 14.72 & 14.77 & 14.81 & 14.89 & 14.93 \\
\hline
\end{tabular}

(After installing the Chute and the Baffle Blocks)

\begin{tabular}{|c|c|c|c|c|c|c|c|c|c|c|c|c|c|}
\hline \multirow[t]{2}{*}{$\begin{array}{l}\text { Test } \\
\text { No. }\end{array}$} & \multirow[t]{2}{*}{$\begin{array}{l}\mathrm{Q} \\
\mathrm{m}^{3} / \mathrm{s}\end{array}$} & \multicolumn{12}{|c|}{$\begin{array}{c}\text { Pressure head } \\
(\mathrm{m})\end{array}$} \\
\hline & & $\mathrm{P}_{1}$ & $\mathrm{P}_{2}$ & $\mathrm{P}_{3}$ & $\mathrm{P}_{4}$ & $\mathrm{P}_{5}$ & $\mathrm{P}_{6}$ & $\mathrm{P}_{7}$ & $\mathrm{P}_{8}$ & $\mathrm{P}_{9}$ & $* \mathrm{P}_{10}$ & $\mathrm{P}_{11}$ & $\mathrm{P}_{12}$ \\
\hline 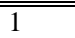 & 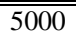 & 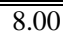 & 99.35 & $\begin{array}{c}10.07 \\
\end{array}$ & 111.07 & $\begin{array}{ll}12.09 \\
\end{array}$ & 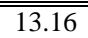 & 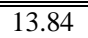 & $\begin{array}{l}13.90 \\
\end{array}$ & \begin{tabular}{|c|}
13.89 \\
\end{tabular} & - & $\begin{array}{c}13.93 \\
\end{array}$ & $\begin{array}{l}13.93 \\
\end{array}$ \\
\hline 10 & 5000 & 7.43 & 8.87 & 9.59 & 10.61 & 11.65 & 12.76 & 13.44 & 13.32 & 13.34 & - & 13.34 & 13.46 \\
\hline 2 & 5500 & 8.33 & 9.67 & 10.43 & 11.41 & 12.45 & 13.49 & 14.14 & 14.18 & 14.20 & - & 14.22 & 14.28 \\
\hline 3 & 6000 & 8.65 & 10.05 & 10.75 & 11.79 & 12.81 & 13.83 & 14.47 & 14.53 & 14.62 & 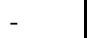 & 14.62 & 14.64 \\
\hline 4 & 7000 & 9.21 & 10.72 & 11.44 & 12.48 & 13.50 & 14.50 & 15.12 & 15.19 & 15.21 & - & 15.35 & 15.44 \\
\hline 6 & 7000 & 9.91 & 11.42 & 12.14 & 13.18 & 14.20 & 15.20 & 15.82 & 15.89 & 15.91 & . & 16.05 & 16.14 \\
\hline
\end{tabular}

- Pizometer cell no. 10 is blocked with Baffle block

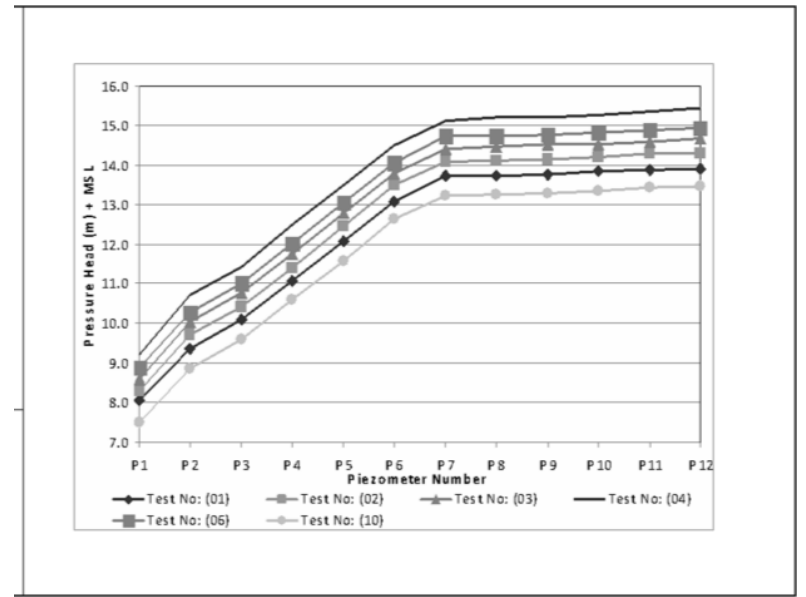

Figure 7a Pressure Distribution

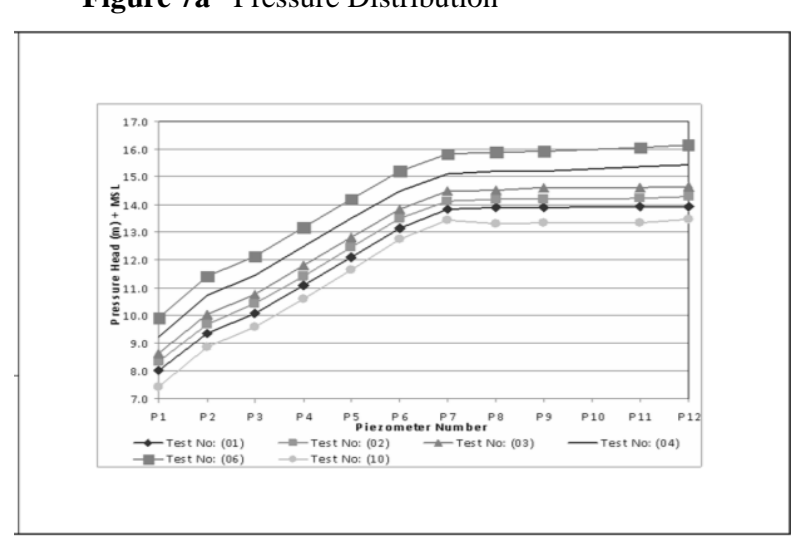

Figure 7b Pressure Distribution 


\section{Appendix (A)}

Table 5 Water Level all over the Model length for Fully Open Gate

- Sill Crest Elevation 41.60 m + MSL- Apron Elevation 36.30 m + MSL

\begin{tabular}{|c|c|c|c|c|c|c|c|c|c|c|c|c|c|c|c|}
\hline Test No. & Q & \multicolumn{14}{|c|}{ Water level $(\mathrm{m})+\mathrm{MSL}$} \\
\hline $\begin{array}{c}\text { Different } \\
\text { discharges were } \\
\text { investigated } \\
\text { ranging from } 5000 \\
\mathrm{~m}^{3} / \mathrm{sec} \text { to } 7000 \\
\mathrm{~m}^{3} / \mathrm{sec} \\
\end{array}$ & $\mathrm{m}^{3} / \mathrm{s}$ & $\begin{array}{l}\text { Head } \\
\text { pond }\end{array}$ & W.L $\mathrm{L}_{1}$ & W.L ${ }_{2}$ & W. $\mathrm{L}_{3}$ & W.L $\mathrm{L}_{4}$ & W.L $\mathrm{L}_{5}$ & W.L 6 & W.L. & W.L 8 & W.L9 & W. $\mathrm{L}_{10}$ & W.L $\mathrm{L}_{11}$ & W. $\mathrm{L}_{12}$ & $\begin{array}{c}\text { Tail } \\
\text { water }\end{array}$ \\
\hline 1 & 25000 & 49.97 & 49.97 & 50.28 & 50.35 & 49.57 & 50.39 & 49.88 & 50.26 & 50.28 & 50.16 & 50.20 & 50.26 & 50.26 & 50.00 \\
\hline 10 & 5000 & 49.70 & 49.70 & 49.76 & 49.93 & 49.07 & 49.30 & 49.34 & 49.91 & 49.86 & 49.84 & 49.80 & 49.78 & 49.86 & 49.55 \\
\hline 2 & 5500 & 50.64 & 50.64 & 50.64 & 50.85 & 49.88 & 50.12 & 50.41 & 50.68 & 50.64 & 50.72 & 50.68 & 50.66 & 50.68 & 50.35 \\
\hline 3 & 6000 & 50.91 & 50.91 & 51.00 & 50.98 & 50.33 & 50.49 & 50.79 & 50.87 & 50.91 & 51.02 & 51.04 & 51.04 & 51.04 & 50.71 \\
\hline 4 & 7000 & 51.69 & 51.69 & 51.73 & 51.93 & 51.17 & 51.28 & 50.93 & 51.63 & 51.86 & 51.69 & 51.67 & 51.69 & 51.67 & 51.45 \\
\hline 6 & 7000 & 51.29 & 51.29 & 51.31 & 51.42 & 50.81 & 51.27 & 50.56 & 51.14 & 51.19 & 51.25 & 51.23 & 51.23 & 51.31 & 51.00 \\
\hline
\end{tabular}

(After installing the Chute and the Baffle Blocks)

\begin{tabular}{|c|c|c|c|c|c|c|c|c|c|c|c|c|c|c|c|}
\hline \multirow{2}{*}{$\begin{array}{l}\text { Test } \\
\text { No. }\end{array}$} & \multirow{2}{*}{$\begin{array}{c}\mathrm{Q} \\
\mathrm{m}^{3} / \mathrm{s}\end{array}$} & \multicolumn{14}{|c|}{ Water level (m) + MSL } \\
\hline & & $\begin{array}{l}\text { Head } \\
\text { pond }\end{array}$ & W.L. ${ }_{1}$ & W.L ${ }_{2}$ & W.L. ${ }_{3}$ & W.L $\mathrm{L}_{4}$ & W.L. & W.L 6 & W. $\mathrm{L}_{7}$ & W.L 8 & W.L9 & W. $\mathrm{L}_{10}$ & W.L $\mathrm{L}_{11}$ & W. $\mathrm{L}_{12}$ & Tail water \\
\hline 1 & 5000 & 50.30 & 50.30 & 50.39 & 50.49 & 49.58 & 50.07 & 50.07 & 50.45 & 50.37 & 50.37 & 50.35 & 50.35 & 50.35 & 50.00 \\
\hline 10 & 5000 & 49.76 & 49.76 & 50.05 & 50.05 & 49.30 & 49.59 & 49.44 & 49.76 & 49.82 & 49.95 & 49.91 & 49.88 & 49.95 & 49.55 \\
\hline 2 & 5500 & 50.64 & 50.64 & 50.75 & 50.80 & 50.00 & 50.35 & 50.66 & 50.66 & 50.66 & 50.68 & 50.70 & 50.70 & 50.35 & 50.35 \\
\hline 3 & 6000 & 51.06 & 51.06 & 51.12 & 51.27 & 50.39 & 50.79 & 50.60 & 50.70 & 51.04 & 51.14 & 51.04 & 51.27 & 51.23 & 50.71 \\
\hline 4 & 7000 & 51.72 & 51.72 & 51.75 & 51.70 & 51.20 & 51.42 & 51.27 & 51.56 & 51.67 & 51.82 & 51.86 & 51.98 & 52.05 & 51.45 \\
\hline 6 & 7000 & 51.29 & 51.29 & 51.31 & 51.42 & 50.80 & 50.72 & 50.56 & 51.14 & 51.19 & 51.25 & 51.23 & 51.23 & 51.31 & 51.00 \\
\hline
\end{tabular}


Table (6) Water Level Drop Over the Sill due to Flow Contraction for Fully Open Gate Sill Crest Elevation (41.60 m) + MSL/- Apron Elevation (36.30 m) + MSL

(Normal Conditions and after 50 years of Bed Degradation)

\begin{tabular}{||c|c|c|c|c|c||}
\hline \hline $\begin{array}{c}\text { Test } \\
\text { No. }\end{array}$ & $\begin{array}{c}\mathrm{Q} \\
\left(\mathrm{m}^{3} / \mathrm{s}\right)\end{array}$ & $\begin{array}{c}\text { U.S.W.L } \\
(\mathrm{m})+\mathrm{MSL}\end{array}$ & $\begin{array}{c}\mathrm{Y} \\
(\mathrm{m})+\mathrm{MSL}\end{array}$ & $\begin{array}{c}\text { D.S.W.L } \\
(\mathrm{m})+\mathrm{MSL}\end{array}$ & $\begin{array}{c}\Delta \mathrm{h} \\
(\mathrm{m})\end{array}$ \\
\hline \hline 1 & 5000 & 49.97 & 49.57 & 50.00 & 0.43 \\
\hline 10 & 5000 & 49.70 & 49.07 & 49.55 & 0.48 \\
\hline 2 & 5500 & 50.64 & 49.88 & 50.35 & 0.47 \\
\hline 3 & 6000 & 50.91 & 50.33 & 50.71 & 0.38 \\
\hline 4 & 7000 & 51.69 & 51.17 & 51.45 & 0.28 \\
\hline 6 & 7000 & 51.29 & 50.81 & 51.00 & 0.19 \\
\hline \hline
\end{tabular}

(After installing the Chute and the Baffle Blocks)

\begin{tabular}{||c|c|c|c|c|c||}
\hline $\begin{array}{c}\text { Test } \\
\text { No. }\end{array}$ & $\begin{array}{c}\mathrm{Q} \\
\left(\mathrm{m}^{3} / \mathrm{s}\right)\end{array}$ & $\begin{array}{c}\text { U.S.W.L } \\
(\mathrm{m})+\mathrm{MSL}\end{array}$ & $\begin{array}{c}\mathrm{Y} \\
(\mathrm{m})+\mathrm{MSL}\end{array}$ & $\begin{array}{c}\text { D.S.W.L } \\
(\mathrm{m})+\mathrm{MSL}\end{array}$ & $\begin{array}{c}\Delta \mathrm{h} \\
(\mathrm{m})\end{array}$ \\
\hline \hline 1 & 5000 & 50.30 & 49.58 & 50.00 & 0.42 \\
\hline 10 & 5000 & 49.76 & 49.30 & 49.55 & 0.25 \\
\hline 2 & 5500 & 50.64 & 50.00 & 50.35 & 0.35 \\
\hline 3 & 6000 & 51.06 & 50.39 & 50.71 & 0.32 \\
\hline 4 & 7000 & 51.72 & 51.20 & 51.45 & 0.25 \\
\hline 6 & 7000 & 51.29 & 50.80 & 51.00 & 0.20 \\
\hline
\end{tabular}

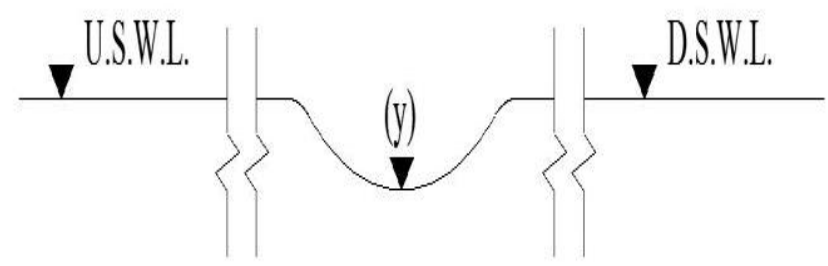


Investigating the Flow Characteristics due to Chute and Baffle Blocks

\section{Appendix B}
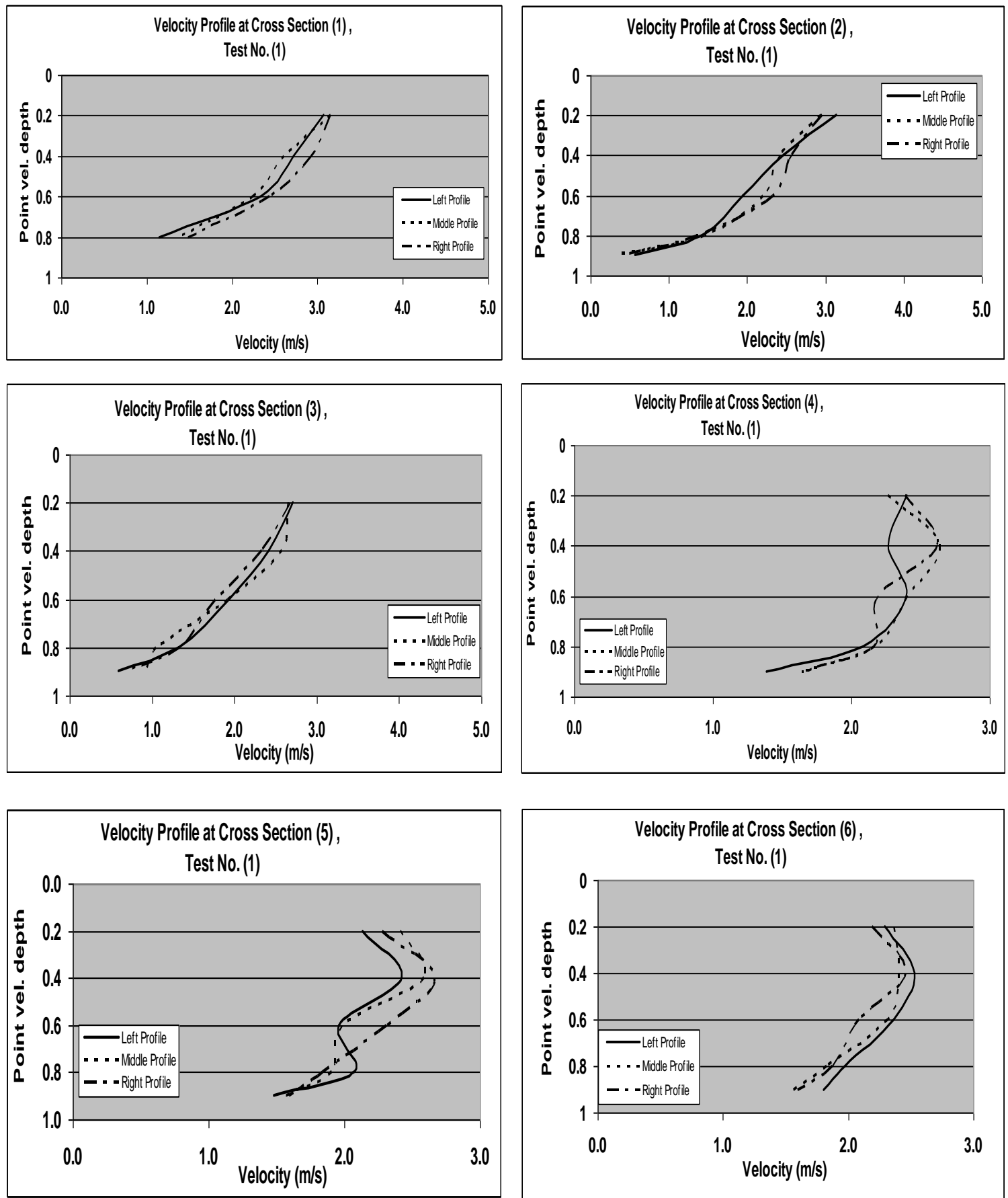

Figure 8a Velocity Distribution, Test No. (1) 

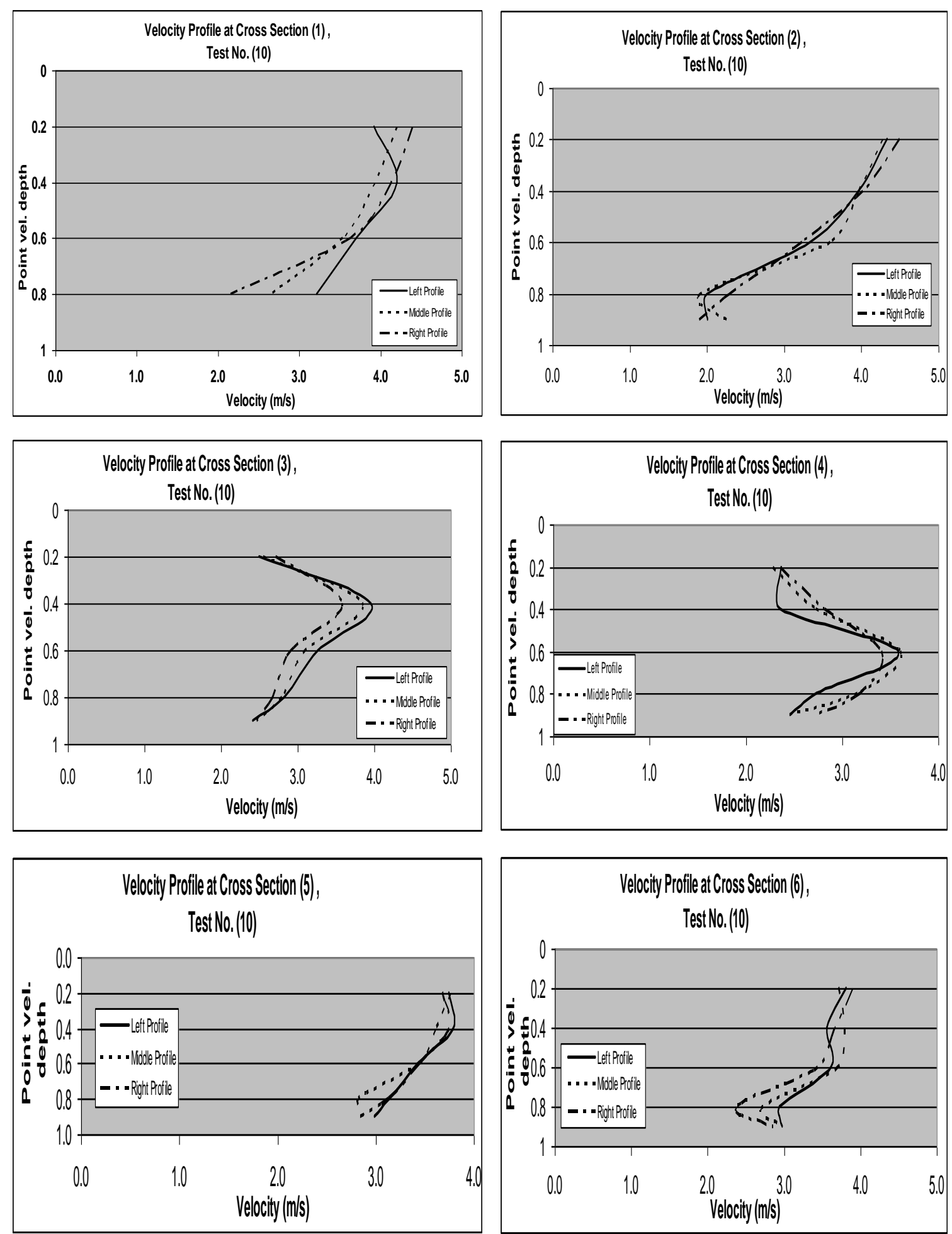

Figure 8b Velocity Distribution, Test No. (10) 